\title{
EKONOMICKÉ ASPEKTY PRÁCE S MLADÝMI NÁVŠTĚVNÍKY ČESKÝCH OPERNÍCH DOMŮ A KONCERTŮ VÁŽNÉ HUDBY
}

Záminkou k práci na uvedené téma byla autorova osobní zkušenost z neobsazených operních domů a koncertních síní, podporovaná jeho trojím působením na pozici vedoucího Klubu mladých při mezinárodním hudebním festivalu Dvorákova Praha. Předmětem zjištování proto bylo, jaké speciální akce pro mladé návštěvníky pořádají pražské festivaly vážné hudby a také všechny české operní domy, aby mladí návštěvníci měli motivaci zaplnit volná (nevyprodaná) místa. Následoval výzkum reprezentativního vzorku členů Klubu mladých z ročníku 2012 festivalu Dvořákova Praha. Členové klubu měli možnost navštívit všechny koncerty festivalu za poplatek $100 \mathrm{Kč}$ splatný na začátku festivalu. Výzkum přiblížil demografické charakteristiky vzorku, stupeň studovaných škol a oborů studia či nejvyšší dosaženého vzdělání rodičů. Dotazník také zjišt'oval počet navštívených koncertů festivalu, spokojenost s jeho programem či žánrovou preferenci zkoumaných, tázal se ale také na to, zda respondenti festival doporučili někomu ze svého okolí, případně kolik dalších mladých návštěvníků přivedli.

Výzkum, který jsme prováděli v rámci diplomové práce Ekonomické aspekty práce s mladými návštěvníky ${ }^{1}$, je možné rozčlenit do těchto tematických částí:

1) Popis nárůstu počtu českých divadel, stálých scén, počtu jejich představení a počet návštěvníků těchto představení v letech 1990 - 2011 spolu s procenty návštěvnosti (tj. ,vyprodaností“ hlediště),

2) popis nárůst počtu českých hudebních souborů v letech 2007 - 2011 se stejnými charakteristikami jako v bodě 1 ),

3) popis nárůst počtu českých operních scén v letech 2007 - 2011 se stejnými charakteristikami jako v bodě 1$)$.

Data ze všech tří výše zmíněných částí shodně vykazovala stejný fenomén ačkoli přibývá scén i představení, návštěvníků je meziročně bud' stejně, anebo dokonce méně. Autor proto pokračoval zjišt’ováním, jak festivaly a operní domy

1 Diplomová práce vedená Mgr. Simonou Škarabelovou, Ph.D. (ESF MU) byla obhájena na Ústavu hudební vědy, Masarykovy univerzity roku 2013. 
pracují s mladým publikem, aby tento úbytek zastavily či alespoň přibrzdily. Následovaly proto části:

4) specifikace mladého publika a popis práce s jednotlivými skupinami mladých návštěvníků ${ }^{2}$ na festivalech vážné hudby pořádaných na území Prahy,

5) práce se stejnými skupinami mladých návštěvníků v operních domech celé ČR,

Po specifikaci pražské konkurence a operních domů např́ič ČR př̌šel autor k popisu výsledků výzkumu, jehož respondenty byl reprezentativní vzorek členů Klubu mladých při mezinárodním hudebním festivalu Dvořákova Praha 2012.

6) Výzkum členů Klubu mladých festivalu Dvořákova Praha ročníku 2012,

7) modelová analýza prodeje zbývajících lístků Národním divadlem Praha

a Národním divadlem Brno mladým návštěvníkům za podmínek specifikovaných $\mathrm{v}$ práci.

Pro účely této studie vybíráme výzkumné okruhy 1) a 6), které představíme ve vzájemné závislosti.

\section{1) Nárůst počtu scén v ČR a počet jejich návštěvníků}

Operní přestavení a koncerty vážné hudby se potýkají se slábnoucí návštěvností svých představení, podobně jako mnohé další instituce věnující se umění. Ačkoliv počet divadelních souborů, počet jimi uváděných premiér i představení rok od roku stoupá, celoroční počet návštěvníků je podle statistiky Ministerstva kultury stále stejný, jak uvádí Tabulka č. 1.

\begin{tabular}{|l|r|r|r|r|r|r|r|r|r|r|r|}
\hline & 1990 & 1991 & 1992 & 1993 & 1994 & 1995 & 1996 & 1997 & 1998 & 1999 & 2000 \\
\hline $\begin{array}{l}\text { Počet divadel (bez } \\
\text { stagion) }\end{array}$ & 47 & 50 & 54 & 53 & 58 & 89 & 91 & 86 & 87 & 116 & 118 \\
\hline Počet stálých scén & 75 & 81 & 82 & 78 & 83 & 96 & 105 & 102 & 99 & 116 & 121 \\
\hline Počet představení & 16319 & 15792 & 14766 & 14215 & 14510 & 18527 & 19620 & 19589 & 20336 & 22655 & 21997 \\
\hline $\begin{array}{l}\text { Počet návštěvníků } \\
\text { (v tis.) }\end{array}$ & 5834 & 4585 & 4288 & 4265 & 4431 & 5247 & 6045 & 5538 & 5733 & 5743 & 4589 \\
\hline
\end{tabular}

\begin{tabular}{|l|r|r|r|r|r|r|r|r|r|r|r|}
\hline & $\mathbf{2 0 0 1}$ & $\mathbf{2 0 0 2}$ & $\mathbf{2 0 0 3}$ & $\mathbf{2 0 0 4}$ & $\mathbf{2 0 0 5}$ & $\mathbf{2 0 0 6}$ & $\mathbf{2 0 0 7}$ & $\mathbf{2 0 0 8}$ & $\mathbf{2 0 0 9}$ & $\mathbf{2 0 1 0}$ & $\mathbf{2 0 1 1}$ \\
\hline $\begin{array}{l}\text { Počet divadel (bez } \\
\text { stagion) }\end{array}$ & 127 & 110 & 101 & 119 & 121 & 125 & 130 & 133 & 137 & 151 & 153 \\
\hline Počet stálých scén & 130 & 129 & 127 & 134 & 143 & 145 & 144 & 148 & 150 & 160 & 169 \\
\hline Počet představení & 23950 & 20857 & 20247 & 23532 & 24563 & 24888 & 25785 & 25703 & 26921 & 26883 & 27959 \\
\hline $\begin{array}{l}\text { Počet návštěvníků } \\
\text { (v tis.) }\end{array}$ & 4405 & 4489 & 4437 & 5149 & 4976 & 5235 & 5448 & 5606 & 5657 & 5805 & 5794 \\
\hline
\end{tabular}

Tab. 1. Nárůst počtu divadelních scén v ČR mezi roky 1990 a 2011.

Zdroj: Statistika kultury 2011, s. 6, www.nipos-mk.cz, zkráceno, upraveno.

2 Tyto skupiny byly převzaty z rozdělení stanoveného samotnými pořádajícími divadly či koncertními domy, povětšinou se jedná o nejmladší návštěvníky (děti nejčastěji od 6 do 15 let věku, $v$ př́ípadech představeni pro školky někdy i děti staré 3 až 6 let) a mladé návštěvníky - studenty ve věku do 26 let 


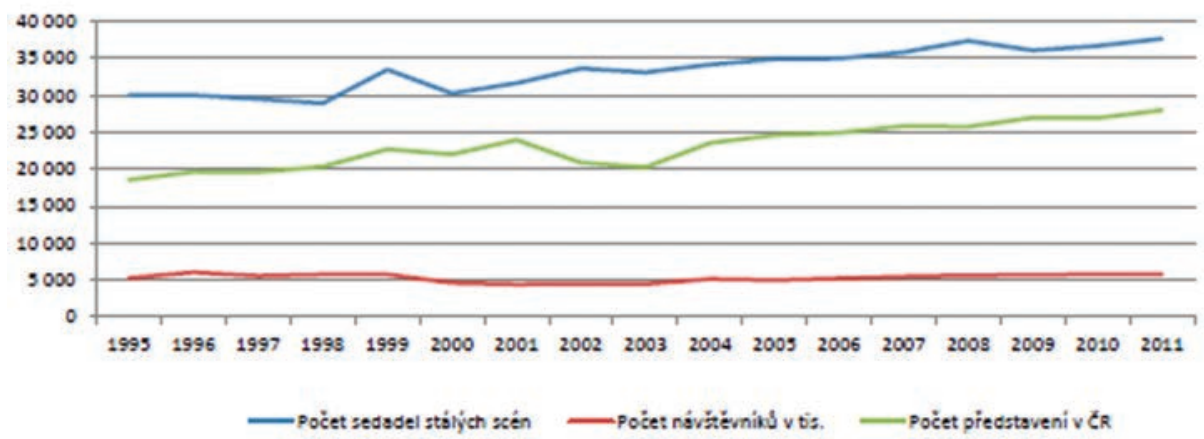

Graf 1 . Nárůst počtu míst ve stálých divadelních scénách, počtu představení těchto scén a počet návštěvníků (v tis.).

Graf, který na základě stejných dat ilustruje narůst počtu stálých divadelních scén v České republice, počet jimi odehraných představeni a konečně počet návštěvníků (uvedený v tisících), uvádíme níže.

Nárůst počtu sedadel i nárůst počtu představení, jež divadelní scény nabízejí, spolu s údajem o téměř stejném počtu návštěvníků za rok naznačuje, že divadla jsou stále méně zaplněná. Tabulka s údaji o návštěvnosti, tj. „vyprodanosti hlediště“, je přiložena níže. Lze vysledovat, že procento návštěvnosti se skutečně snižuje - u činohry byla přes meziroční nárůst v letech 2002 až 2010 úroveň návštěvnosti v roce 2011 nižší než v roce 2007, u opery došlo v posledním sledovaném roce k prudkému poklesu až na dvě třetiny, z nichž bývá hlediště zaplněné. Návštěvnost koncertů ve vlastní režii je téměř neměnná.

\begin{tabular}{|c|c|c|c|c|c|}
\hline \multicolumn{3}{|c|}{ Procento návštěvnosti z nabízených míst v ČR } & \multirow[b]{2}{*}{2009} & \multirow[b]{2}{*}{2010} & \multirow[b]{2}{*}{2011} \\
\hline & 2007 & 2008 & & & \\
\hline celkem & 79,7 & 80,3 & 81,3 & 81,6 & 77,8 \\
\hline činohra & 78,3 & 82,3 & 81,5 & 82,2 & 77,6 \\
\hline opera & 76,6 & 73,5 & 74,4 & 74,3 & 67,7 \\
\hline koncerty ve vlastní režii & 77,3 & 75 & 72,9 & 74,8 & 78 \\
\hline opereta & 82,3 & 88,2 & 83,5 & 84,8 & 78,8 \\
\hline muzikál & 88,3 & 86,1 & 93,2 & 91,1 & 90,2 \\
\hline balet & 77,7 & 78,6 & 78,9 & 75,2 & 75,1 \\
\hline tanec a pohybové divadlo & 89,6 & 79,9 & 76,1 & 78,1 & 55 \\
\hline loutkové divadlo & 86,6 & 79,4 & 86,1 & 84,9 & 84,8 \\
\hline literární večery & 69,9 & 78,2 & 48 & 60,9 & 74,1 \\
\hline multimediální & 55 & 52,5 & 51,2 & 87,9 & - \\
\hline ostatní & 82 & 81 & 82,8 & 69,6 & 67,9 \\
\hline pro děti a mládež & 84 & 83,4 & 86,5 & 83,3 & 84 \\
\hline
\end{tabular}

Tab. 2. Procento návštěvnosti českých a moravských divadel aj. míst.

Zdroj: Statistika kultury 2011, s. 13, www.nipos-mk.cz, zkráceno, upraveno (doplněny koncerty ve vlastní režii). 
Autor proto na základě výše uvedených údajů o klesající návštěvnosti zjišt’oval, jaké akce a programy divadla s operními domy nabízejí pro nejmladší a mladé návštěvníky, aby tito navštěvovali jejich představení a vytvářeli budoucí návštěvnickou obec. Zároveň bylo zjišt'ováno, jak jsou tyto programy prezentovány (zda na úvodní www stránce, zda jsou jednotné pro všechny scény divadla atp.). Výsledky výzkumu, které byly pochopitelně poplatné době vzniku práce vyjadřovaly realitu roku 2013 - jsou $\mathrm{k}$ vidění v diplomové práci.

\section{6) Výzkum členů Klubu mladých festivalu Dvořákova Prahy 2012}

Stěžejní částí práce byl výzkum členů Klubu mladých, jehož vedoucím byl autor v letech 2010 - 2012 a který sám navštěvoval v letech 2008 - 2010 coby mladý návštěvník. Vznik Klubu je svázán s osobou prvního intendanta festivalu Vladimíra Darjanina, který se rozhodl dát $\mathrm{k}$ dispozici volná místa mladým lidem a zř́́dil kvưli tomu právě Klub mladých. ${ }^{3}$ Jeho členové mohli za vstupní poplatek 100 Kč navštívit všechny večerní koncerty festivalu bez jakékoli další peněžní úhrady, pouze bylo nutné akreditovat se na jednotlivé koncerty. Zároveň směli navštívit odpolední koncerty série „debut“, na kterých ovšem dopláceli 50 Kč.

Výzkum byl realizován formou webového dotazníku, jehož webová adresa byla rozeslána všem členům Klubu mladých ročníku 2012 prostřednictvím emailu. Dotazník odeslalo celkem 62 respondentů, výsledky šetření shrnujeme níže.

\section{Základní charakteristiky vzorku}

Těchto 62 respondentů v otázce týkající se množství koncertů navštívených na Dvoř́kově Praze v roce 2012 uvedlo, že navštívili dohromady 332 koncertů (průměrně navštívil jeden respondent 5 koncertů). Jelikož celkový počet akreditací mladých návštěvníků vydaných na ročník 2012 festivalu činil 1240 kusů, reprezentuje výše zmíněný počet navštívených koncertů $26,7 \%$ návštěv všech členů Klubu mladých 2012 Dvořákovy Prahy. Počet návštěv jednotlivých koncertů mladými návštěvníky spolu se stručným programem ukazuje seznam koncertů níže.

\begin{tabular}{|c|c|l|c|}
\hline datum & návštěvníků & Interpret a koncert & $\begin{array}{c}\text { cena běžného } \\
\text { lístku }\end{array}$ \\
\hline 8.9. & $\mathbf{5 6}$ & $\begin{array}{l}\text { Orchestre philharmonique de Luxemburg - Sibeliův houslový } \\
\text { k., Dvořákova Novosvětská }\end{array}$ & $490-1490$ \\
\hline 9.9. & $\mathbf{9 4}$ & $\begin{array}{l}\text { Orchestre philharmonique de Luxemburg - Sibeliův houslový } \\
\text { k., Dvořákova Novosvětská }\end{array}$ & $490-1390$ \\
\hline
\end{tabular}

3 Volnými místy jsou míněna místa nejen nevyprodaná, nýbrž i neobsazená - nevyčerpaná místa sponzorů, nedorazivších běžných návštěvníků apod., čili veškerá zbylá místa v okamžiku začátku koncertu. 


\begin{tabular}{|c|c|c|c|}
\hline datum & návštěvníků & Interpret a koncert & $\begin{array}{l}\text { cena běžného } \\
\text { lístku }\end{array}$ \\
\hline 10.9. & 66 & $\begin{array}{l}\text { Houslista Gilles Apap a Pražský komorní orchestr - Kreisler, } \\
\text { Mozart, Grieg, Vivaldi }\end{array}$ & $250-690$ \\
\hline 11.9. & 60 & Klavírista Thibaudet a Debussyho skladby & $250-690$ \\
\hline 12.9. & 56 & Bannewitzovo kvarteto & $150-490$ \\
\hline 13.9. & 52 & Pěvkyně Marina Rebeka a klavírní doprovod & 290-990 \\
\hline 14.9. & 62 & ČF - Brahms, Dvořák, Čajkovský & $290-990$ \\
\hline 15.9. & 62 & ČF - Dvořák,Brahms, Čajkovský & 290-990 \\
\hline 16.9. & 66 & ČF a Český filh. Sbor Brno - Brahms, Čajkovský, Dvořák & $290-990$ \\
\hline 17.9. & 95 & $\begin{array}{l}\text { SOČR FOK a Pražský filh. sbor - Dvořákovo Requiem, KATED- } \\
\text { RÁLA }\end{array}$ & 990 \\
\hline 18.9. & 102 & SOČR FOK - Berlioz, Čajkovský, Respighi, Ravel & $250-790$ \\
\hline 19.9. & 142 & Staatskapelle Dresden, Mehta - Hindemith, Dvořák, Strauss & $490-2490$ \\
\hline 20.9. & 112 & ČF - Strauss, Beethoven, Brahms & $490-1590$ \\
\hline 21.9. & 109 & $\begin{array}{l}\text { Youth orchestra of Caracas, Šostakovič, Čajkovský, Saint-Saëns } \\
+ \text { latinskoamerická hudba }\end{array}$ & $290-1490$ \\
\hline 22.9. & 106 & ČF - Beethoven, Dvořák & $490-1490$ \\
\hline
\end{tabular}

Tab. 3. Seznam koncertů festivalu Dvořákova Praha, ročník 2012, s uvedením počtu akreditovaných mladých návštěvníků a ceny běžných vstupenek.

Věk návštěvníků musel být s ohledem na podmínky členství v Klubu mladých nižší než 26 let, tabulku s popisem počtu návštěvníků všech věkových skupin uvádíme níže:

\begin{tabular}{|c|c|}
\hline věk & počet \\
\hline 16 & 3 \\
\hline 17 & 7 \\
\hline 18 & 1 \\
\hline 19 & 6 \\
\hline 20 & 5 \\
\hline 21 & 11 \\
\hline 22 & 11 \\
\hline 23 & 1 \\
\hline 24 & 9 \\
\hline 25 & 5 \\
\hline 26 & 3 \\
\hline $\mathbf{m = 2 1 . 1 9}$ & $\mathbf{6 2}$ \\
\hline
\end{tabular}

Tab. 4. Počet mladých návštěvníků podle věku.

Počtem 38 osob ze vzorku 62 mladých návštěvníků festivalu tvořily ženy $61 \%$ většinu; muži byli zastoupeni 24 osobami, které představovaly $39 \%$ část vzorku. Tento výsledek je ve shodě s předešlými výzkumy návštěvníků - Bačuvčík ${ }^{4}$ ve své knize o publiku moravských symfonických orchestrů uvádí na základě

4 BAČUVČÍK, Radim. Marketing symfonických orchestrü: publikum a veřejnost moravských filharmonii. 1. vyd. Zlín: Verbum, 2011, 184 s. ISBN 9788087500033 
výzkumu publika Filharmonie Brno, že ženy obvykle tvoří v oblasti kultury dominantní část publika, zvláště jedná-li se o tzv. performativní umění. ${ }^{5}$

\section{Zjištění o samotných návštěvnících}

\section{a) Škola studovaná mladými návštěvníky}

Mladí návštěvníci Dvořákovy Prahy studovali nejčastěji vysokou školu - bylo tomu tak ve 44 př́ípadech, což odpovídá 70,96\% vzorku, jeden další respondent studoval uměleckou vysokou školu. Je proto možné uvést, že celkově tvořili vysokoškoláci téměř tři čtvrtiny (přesně 72,57\%) respondentů. Celkem 9 návštěvníků studovalo gymnázium (bez upřesnění, zda se jedná o osmi, šesti či čtyřleté gymnázium), gymnazisté tedy tvořili $14,51 \%$ ze skupiny mladých návštěvníků. Pět osob studovalo na konzervatoři $(8,06 \%$ všech návštěvníků). Dva studenti (3,22\% ze vzorku) byli žáky středních škol ukončených maturitou, jeden mladý návštěvník studoval na vyšší odborné škole (1,6\% všech voleb). Mezi respondenty nebyl žádný student střední školy bez maturitní zkoušky ani učebního oboru.

Výsledky ilustruje následující graf.

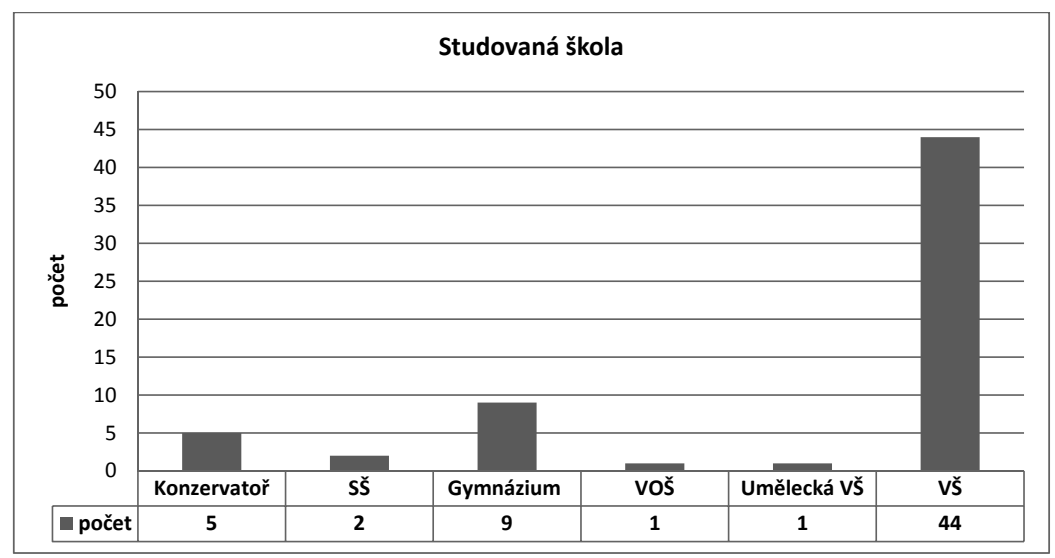

Graf 2. Škola studovaná mladými návštěvníky.

\section{b) Obor studované vysoké školy}

Poslední otázkou týkající se vzdělání bylo zjištování oboru vysoké školy, kterou respondenti studují. Za nejjednodušší dělení této oblasti lze považovat dělení na technické a humanitní obory. Výsledek výzkumu ukázal, že celkem 29 ze 45 studentů vysokých škol, což jsou téměř dvě třetiny respondentů, studovalo jinou nežli humanitně či sociálně-vědně zaměřenou vysokou školu.

Mezi nehumanitní obory, které uvedl za svi̊j obor více než jeden respondent, patřila Medicína (4 respondenti), Kybernetika a robotika (3 respondenti), Infor- 
matika (3 respondenti) a Fyzika (2 respondenti). Seznam všech oborů je k vidění $\mathrm{v}$ príloze celé diplomové práce.

\section{c) Vzdělání rodičů mladých návštěvníků}

Otázkou na vzdělání rodičů se autor pokoušel zjistit očekávanou aspiraci respondentů. Lze totiž očekávat, že potomci vysokoškolsky vzdělaných rodičů budou sami aspirovat k dosažení vysokoškolskému vzdělání.

Zároveň otázka mohla představovat exkurz do poměrů rodiny, jelikož u vysokoškolsky vzdělaných osob je možné očekávat vyšší výdělek a tím i lepší situaci rodiny. Byly určeny tyto možnosti odpovědi: A) základní škola, učiliště či stř̌ední škola bez maturity, B) střední škola s maturitou, C) gymnázium, D) vysoká škola a E) umělecké VŠ jako specifická kategorie.

Tato část dotazníku navíc mohla odpovídat na otázku, zda poslech vážné hudby/návštěva jejích koncertů na festivalu nějakým způsobem souvisí s dosaženým vzděláním. Jak zmiňuje Dimitrov ve svém výzkumu publika operního festivalu Janáček Brno 2012: „Struktura konzumentů operního umění podle vzdělání mívá obecně ze všech demografických ukazatelů nejvíce homogenní charakter. Nikoli překvapivě je to dáno majoritním zastoupením vysokoškolsky vzdělaných návštěvníkư ${ }^{6.6}$

Výsledky by proto mohly nastínit, zda je podobná úvaha možná i v př́padě konzumentů nikoli opery, nýbrž konzumentů koncertů vážné hudby.

Výsledky otázky na vzdělání rodičů mladých respondentů z Dvořákovy Prahy přináším níže.

\begin{tabular}{|l|c|c|}
\hline & vzdělání matka & vzdělání otec \\
\hline Ž̌, učiliště, sś bez mat. & 2 & 6 \\
\hline Stř́ední škola s mat. & 20 & 12 \\
\hline Gymnázium & 2 & 1 \\
\hline VŠ & 37 & 39 \\
\hline Umělecká vš & 1 & 4 \\
\hline
\end{tabular}

Tab. 5. Vzdělání rodičů respondentů Dvořákovy Prahy.

Již z prostého pohledu na čísla je zřejmé, že ve vzorku bylo velké množství rodičů s vysokou školou. Mezi rodiči mladých návštěvníků bylo takřka $60 \%$ vysokoškolsky vzdělaných matek a téměř $63 \%$ stejně vzdělaných otců. Autor se proto rozhodl pro dodatečné zjištění, kolik respondentů z řad Klubu mladých má vysokoškolsky vzdělané oba rodiče a výsledky rovněž přináší: 31 respondentů měli oba dva rodiče vysokoškolsky vzdělané, dva respondenti měli jednoho z rodičů s ,běžnou“ vysokou školou a druhého s uměleckou vysokou školu a konečně jeden z respondentů měl oba rodiče vzdělané na umělecké vysoké škole.

6 DIMITROV, P. Sociologický průzkum publika festivalu Janáček Brno 2012. Vybrané sociologické aspekty. Brno, 2013. 104 s. Diplomová práce na Filozofické fakultě Masarykovy univerzity na Ústavu hudební vědy. Vedoucí diplomové práce Mikuláš Bek 
V součtu výše zmíněných kategorií statistika z výzkumu dokládá vysokoškolské vzdělání obou rodičů u 34 členů Klubu mladých, čili téměř $55 \%$ vzorku jeho členů mělo oba dva rodiče s vysokou školou. Výsledky ukazují, že mladí návštěvníci Dvořákovy Prahy pocházeli často z velmi specifického prostředí s vysoce vzdělanými rodiči. Implikace tohoto zjištění je pochopitelně složitá, ovšem faktem zůstává, že v tomto ohledu je reprezentativní vzorek mladých návštěvníků festivalu vysoko nad normálním rozložením v populaci ${ }^{7}$. Ze stejného faktu lze vyvozovat, že ekonomická situace rodin respondentů je nadprůměrně dobrá, jelikož s vyšším vzděláním povětšinou stoupá i životní úroveň.

\section{Zjištění týkající se návštěv na festivalu}

Celkový počet akreditací vydaných na ročník 2012 festivalu Dvořákova Praha činil 1240 kusů. Respondenti v dotazníku uvedli, že v součtu navštívili 332 koncertů stejného festivalu, tudíž návštěvy respondentů na koncertech reprezentují 26,7 \% návštěv všech mladých návštěvníků na festivalu. Shrnutí základních popisných charakteristik týkajících se návštěv respondentů na koncertech Dvořákovy Prahy 2012 uvádím níže.

\begin{tabular}{|l|l|l|}
\hline $\mathbf{m}$ & průměrný počet návštěv koncertů & $\mathbf{5 , 4 4}$ \\
\hline $\mathbf{m i n}$ & minimálně navštíveno večerních koncertů & $\mathbf{0}$ \\
\hline $\mathbf{m a x}$ & maximálně navštíveno večerních koncertů & $\mathbf{1 4}$ (všechny nabízené) \\
\hline modus $^{8}$ & nejčastěji navštíveno koncertů & $\mathbf{4}$ \\
\hline median $^{9}$ & prostřední hodnota & $\mathbf{5}$ \\
\hline
\end{tabular}

Tab. 6. Počet návštěv členů Klubu mladých na ročníku 2012.

Počet návštěv koncertů jednotlivými mladými návštěvníky na zkoumaném ročníku festivalu shrnuje následující tabulka.

7 Pokud bychom pro jednoduchost uvažovali situaci před 10 lety, kdy bylo v ČR podle ČSÚ 762459 vysokoškoláků, dále uvažovali přesně 10 milionů obyvatel v ČR a rozdělení $1 / 2$ absolventů VŠ na ženy a stejnou část na muže, bylo by zastoupení vysokoškolsky vzdělaných mužů v populaci 7,62\% (podle vzorce 100/(5,000.000 / 381229), zastoupení žen rovněž 7,62\%. I kdyby si všechny vysokoškolsky vzdělané ženy vzaly vysokoškolsky vzdělané muže (což je nereálná situace kvůli měnícímu se zastoupení vysokoškoláků v různých věkových kohortách), bylo by maximální možné zastoupení vysokoškolsky vzdělaných párů v zemi před 10 lety právě $7,6 \%$. Zastoupení obou rodičů s vysokou školou ve vzorku respondentů je přitom téměř osmkrát vyšší.

8 Modus je nejčastěji uváděná hodnota

9 Median je hodnota přesně uprostřed všech hodnot uvedenými respondenty 


\begin{tabular}{|c|c|}
\hline Celkový počet návštěv na večerním koncertu & Počet návštěvníků \\
\hline $\mathbf{0}$ & 1 \\
\hline $\mathbf{1}$ & 5 \\
\hline $\mathbf{2}$ & 7 \\
\hline $\mathbf{3}$ & 5 \\
\hline $\mathbf{4}$ & 10 \\
\hline $\mathbf{5}$ & 9 \\
\hline $\mathbf{6}$ & 7 \\
\hline $\mathbf{7}$ & 3 \\
\hline $\mathbf{8}$ & 5 \\
\hline $\mathbf{9}$ & 2 \\
\hline 10 & 4 \\
\hline 11 & 0 \\
\hline 12 & 2 \\
\hline 13 & 0 \\
\hline 14 & 2 \\
\hline
\end{tabular}

Tab. 7. Četnost návštěv večerních koncertů jednotlivými mladými návštěvníky.

V návaznosti na otázku týkající se počtu navštívených koncertů se autor rozhodl zjistit, kolikátého ročníku se respondenti účastnili. 11 mladých návštěvníků se účastnilo festivalu poprvé (což odpovídá $17 \%$ všech respondentů), 36 návštěvníků ( $58 \%$ všech respondentů) se účastnilo druhého ročníku. Třetí ročník navštívilo 11 respondentů $(17,7 \%$ všech respondenti̊) a čtvrtého ročníku se účastnili 4 respondenti $(6,4 \%$ všech respondentů). Bylo tedy možné vysledovat kontinuitu návštěv na festivalu.

\section{Spokojenost s programem festivalu}

Návštěvníkům byla v dotazníku rovněž dána otázka ve znění: „Vyznačte vaši spokojenost $s$ programem festivalu $(1=$ nejméně až $10=$ nejvíce $)$, " přičemž jako odpověd’ byla k označení připravena políčka s hodnotami 1 až 10. Číselné hrnutí odpovědí respondentů na tuto otázku přináším dále.

\begin{tabular}{|l|c|}
\hline škála spokojenosti s programem DP & Počet odpovědí \\
\hline hodnota 10 & 16 \\
\hline hodnota 9 & 15 \\
\hline hodnota 8 & 11 \\
\hline hodnota 7 & 6 \\
\hline hodnota 6 & 5 \\
\hline hodnota 5 & 0 \\
\hline hodnota 4 & 0 \\
\hline hodnota 3 & 0 \\
\hline hodnota 2 & 1 \\
\hline hodnota 1 & $\mathbf{8}$ \\
\hline
\end{tabular}

Tab. 8. Škála spokojenosti s programem. 
Průměrná hodnota spokojenosti s programem mezi respondenty byla 7,5. Minimální označená spokojenost byla $1(\mathrm{n}=8)$, maximální spokojenost $10(\mathrm{n}$ $=16$ ). Medián (hodnota uprostřed všech voleb) byl 5,5; modus jako nejčastěji označená hodnota byl 10 (v 16 př́ípadech).

\section{Nejméně spokojení návštěvníci}

Kvůli nezanedbatelnému množství respondentů ( $\mathrm{n}=8$; tedy téměř $13 \%$ celku), kteří označili nejnižší možnou spokojenost s programem (hodnotu 1), analyzoval autor rovněž chování právě této „nespokojené“ skupiny návštěvníků.

Osm mladých návštěvníků nejméně spokojených s programem festivalu $(\mathrm{n}=$ 8) navštívilo dohromady 38 večerních koncertů. Počet koncertů navštívených jednotlivými mladými návštěvníky byl tento:

$2 ; 2 ; 4 ; 4 ; 5 ; 5 ; 6 ; 10$.

Vyjma prvních dvou hodnot se jedná o čísla, která jsou blízká průměrnému počtu návštěv mezi mladými návštěvníky - průměrný počet návštěv u všech respondentů byl 5,35 a průměrný počet návštěv ve skupině nejméně spokojených mladých návštěvníků byl 4,75. Hlubší analýza návštěv nespokojenými návštěvníky by vyžadovala kvalitativní výzkum, pakliže se ovšem nejedná o chybu zadávání dat respondenty ( $\mathrm{v}$ prípadě 10 navštívených koncertů ze 14 lze jen těžko věrit, že by byl respondent silně nespokojený s programem).

Jedno z možných vysvětlení tohoto jevu je, že návštěvníci chodili také na koncerty, ačkoli tyto nebyly svým programem přesně podle jejich gusta - nabídka špičkových interpretů totiž nezáživnost programu může přebít.

Takový postup ovšem není proti celkové ideji, že umožníme-li mladým lidem chodit za výhodných podmínek na (vážnou) kulturu, můžeme doufat v jejich návrat $\mathrm{v}$ pozdějším věku.

Je třeba podotknout, že nejvíce mladých návštěvníků přišlo v daném ročníku festivalu na koncert Staatskapelle Dresden se Zubinem Mehtou. Na programu byla Hindemithova předehra Neues vom Tage, Dvořákův violoncellový koncert č. 2 h-moll a poté Symphonia Domestica od Richarda Strausse. Takový program patř́ celkem bez pochyby k náročnějším, přesto byl navštíven více než 140 mladými lidmi.

\section{Doporučení přátelům k návštěvě festivalu}

Závěrečné otázky zjišt'ovaly, zda o nabídce festivalu řekli respondenti přátelům ze svého okolí, zda sami nějaké nové členy Klubu mladých přivedli a také zda hodlají festival navštěvovat i po dosažení 26 let věku. 61 studentů ze 62 podle údajů z dotazníků doporučilo festival lidem ze svého okolí; rovněž 41 respondentů uvedlo, že sami nějakého dalšího mladého návštěvníka na festival přivedli. Zmíněných 41 respondentů podle výsledku šetření přivedlo celkem 95 mladých návštěvníků, přesné výsledky dokumentuje tabulka níže. 


\begin{tabular}{|c|c|}
\hline počet přivedených návštěvníků & četnost \\
\hline 1 & 16 \\
\hline 2 & 12 \\
\hline 3 & 6 \\
\hline 4 & 3 \\
\hline 5 & 1 \\
\hline 6 & 1 \\
\hline 7 & 2 \\
\hline
\end{tabular}

Tab. 9. Počet přivedených návštěvníků.

Tento nárůst počtu mladých návštěvníků v průběhu festivalu dokládají i data týkající se počtu akreditací na jednotlivé koncerty festivalu. 55 respondentů ( $88 \%$ celku) uvedlo, že by festival rádo navštěvovalo i po dovršení 26 let věku, kdy ztratí možnost využívat levné kartičky Klubu mladých.

\section{Výsledek výzkumu mladých návštěvníků}

Jak ukazují data z výzkumu, mladí návštěvníci jsou skupinou publika, s níž lze pracovat a která může přinést i jistý ekonomický profit. Hlavním cílem práce bylo ovšem přinést důkaz pro názor, že pokud se mladému diváku za rozumnou sumu umožní divadlo či koncert navštívit a zažít jeho atmosféru, do instituce se vrátí. Lze se jen těžko domnívat, že mladý návštěvník dosažením 26. roku věku silně změní své hudební preference a začne namísto na koncerty České filharmonie chodit výhradně napřr. na koncerty death-metalu ${ }^{10}$ a vážnou hudbu zcela opustí.

$\mathrm{V}$ práci byly ještě vytvořeny modelové situace u Národního divadla Praha a Národního divadla Brno a jejich operních scén, které lze vnímat jako blízké festivalu vážné hudby. Zde přináší jen statistiky volných míst, aby ilustroval fakta zmíněná na předešlých řádcích. Při operních inscenacích na všech scénách Národního divadla Praha zůstalo v roce 2012 volných 118664 míst $^{11}$. Na jedno operní představení připadá $\mathrm{v}$ průměru 290 volných míst. Při operních inscenacích Národního divadla Brno zůstalo v roce 2011 volných 37270 míst. ${ }^{12} \mathrm{Na}$ jedno operní představení proto připadá v průměru 245 volných míst.

Autorovou snahou bylo v každé z těchto institucích založit klub podobný Klubu mladých. Zástupci divadel však nechtějí dát mladým návštěvníkům možnost jít do divadla za podobných podmínek, jako mohli chodit na Dvořákovu Prahu -

10 Death-metall byl vybrán jen jako př́klad žánru, jehož oblibu lze u návštěvníků vážné hudby očekávat s malou pravděpodobností; tento př́iklad není dokladem autorovy zášti k death-metallu, má čistě ilustrativní charakter.

11 Národní divadlo. Výroční zpráva o činnosti a hospodaření v roce 2012. [online]. www.narodni-divadlo.cz.

12 Národní divadlo Brno. Zprávy o činnosti příspěvkové organizace Národní divadlo Brno za rok 2011 [online] 2013 [cit. 1. ledna 2013]. Dostupné z < www.ndbrno.cz/file/3359_1_1/ $>$. 
zmiňovali nejčastěji nutnost platit alespoň $200 \mathrm{Kč} \mathrm{za} \mathrm{lístek} \mathrm{na} \mathrm{jedno} \mathrm{představení,}$ aby se mladí návštěvníci naučili znát cenu živého umění. Že se mladí lidé znát cenu takového umění nenaučí, poněvadž představení vůbec nenavštíví, nikomu nevadí.

Obě instituce, příspěvkové organizace, placené z daní všech obyvatel ČR, jako by tím udržovaly status quo. Chtějí ukázat, že mají nevyprodáno, a tedy potřebují př́spěvek.

Jan Jiří Buchta (jjb@mail.muni.cz), Ústav hudební vědy, Filozofická fakulta, Masarykova univerzita, Brno, CZ.

\section{ABSTRACT \\ ECONOMICAL ASPECTS OF YOUNG AUDIENCE PROGRAMMES OF THE CZECH OPERA HOUSES AND OF THE CLASSICAL MUSIC CONCERTS}

The present paper points out, that special approach to young audience could bring very specific advantages and benefits to organisations, which provide these special programs. At first it describes the level of crowdedness of performance of all Czech theatres, opera houses and at the concerts of classic music. Author than describes all programs of Czech opera houses for young audience and the same programs of Classical music festivals in Prague. He means that it would earn the organisations many benefits to offer empty seats to young auditorium instead of leaving them empty. Thanks to advertising and other effects connected with such programs this action could be profitable, mainly for the future of opera houses as well as for festivals of classical music.

\section{Key words}

music, opera, classic music, concerts, auditorium, benefits, Young auditorium club, Dvořákova Praha, festival

\section{Bibliography}

Atelier pro děti a mládež. Národní divadlo Moravskoslezské Ostrava. Webová stránka, Dostupné z <www.ndm.cz/cz/stranka/118-atelier-pro-deti-a-mladez-workshopy-metodicka-podpora-pracovni-listy.html>.

BAČUVČÍK, R. Marketing kultury: Divadlo, koncerty, publikum, veřejnost. Zlín: VeRBum, 2012. BEK, M. Konzervatoř Evropy? K sociologii české hudebnosti. Praha: KLP, 2003.

Česká filharmonie. Webová stránka. Dostupné z: <www.ceskafilharmonie.cz>.

Český statistický úřad. Počet obyvatel v letech 150 - 2011.[online]. 2012 [cit. 2013-1-12]. Dostupné z: <http://www.czso.cz/csu/redakce.nsf/i/pocet_obyvatel_v_letech_1950_2011>.

DIMITROV, P. Sociologický průzkum publika festivalu Janáček Brno 2012. Vybrané sociologické aspekty. Brno, 2013. 104 s. Diplomová práce na Filozofické fakultě Masarykovy univerzity na Ústavu hudební vědy. Vedoucí diplomové práce Mikuláš Bek. Dostupné z: <is.muni.cz>.

Divadlo Josefa Kajetána Tyla Plzeň. Webová stránka. Dostupné z: <www.djkt-plzen.cz $>$.

Dvořákova Praha. Webová stránka, Dostupné z: <www.dvorakovapraha.cz $>$.

EDGERS, G. Old masters, new buzz: With 'street teams,' Gardner Museum courts younger set. Boston Globe, June 21, 2008 Dostupné z: <www.boston.com/ae/theater_arts/articles/2008/06/21/ old_masters_new_buzz/?page=full $>$. 
Isabella Stewart Gardner museum of art. Audience research. Young Adult Study. Prepared by Randi Korn \& Associates, Inc. [online] July 2008 [cit. 28. [února 2013]. Dostupné z: <http://www. wallacefoundation.org/knowledge-center/audience-development-for-the-arts/strategies-for-expanding-audiences/Documents/Audience-Research-Young-Adult-Study.pdf $>$.

Jihočeské divadlo. Webová stránka, Dostupné z: <www.jihoceskedivadlo.cz>.

Katalog předplatného na sezonu 2013/2014. Moravské divadlo Olomouc. [online] n.d. [cit. 1. února 2012]. Dostupné z: <http://www.moravskedivadlo.cz/media.php?a=file\&id=1148>.

KOLB, B. M. Classical Music Concerts Can Be Fun: The Success of BBC Proms. In International journal of arts management [online] 1998. Dostupné $\mathrm{z}:<\mathrm{http}: / /$ zonecours.hec.ca/documents/ A2004-1-154717.03Kolb\%285\%29.pdf>.

Mládež a kultura. Šaldovo divadlo. Webová stránka, Dostupné z UR: <http://www.saldovo-divadlo.cz > Moravské divadlo Olomouc. Dostupné z: <www.moravskedivadlo.cz/moravske-divadlo $>$.

Mrazík, metodické listy. Webová stránka, Dostupné z: <http://www.ndm.cz/userfiles/archiv_priloh/ clanky/loga-a-jine/metodicke-listy-1323995171.pdf>.

Národní divadlo Brno. Webová stránka, Dostupné z: <www.ndbrno.cz>.

Národní divadlo Praha. Webová stránka, Dostupné z: <www.narodni-divadlo.cz $>$.

Národní divadlo moravskoslezské Ostrava. Webová stránka. Dostupné z: <www.ndm.cz $>$.

Národní informační a poradenské středisko pro kulturu. Základní statistické údaje o kultuře v české republice 2011, II. díl. Umění. Divadla, hudební soubory, výstavní činnost a festivaly. [online] n.d. [cit. 1. února 2012]. Dostupné z: <www.nipos-mk.cz/wp-content/uploads/2009/03/Statistika_kultury_2011_II.UMENI_web.pdf $>$.

NEKOLNÝ, B. Opera naše drahá [online] 2012 [cit. 1. ledna 2013]. Dostupné z: <host.divadlo.cz/ box/doc/sprava_a rizeni/OperaA2.doc $>$.

Nová scéna. Národní divadlo. Webová stránka, Dostupné z: <www.novascena.cz/cs/vstupenky/2. html>.

Pracovní listy NDM. Webová stránka, Dostupné z: <www.ndm.cz/cz/stranka/118-atelier-pro-deti-a-mladez-workshopy-metodicka-podpora-pracovni-listy.html $>$.

Pražské jaro. Webová stránka festivalu. Dostupné z: $<$ www.festival.cz $>$.

Pražský podzim. Webová stránka. Dostupné z: <www.prazskypodzim.cz>.

Pro školy. Národní divadlo moravskoslezské Ostrava. Webová stránka, Dostupné z: <www.ndm.cz/ cz/stranka/117-predstaveni-pro-skoly.html>.

Rozhlasový podzim. Webová stránka, Dostupné z: <www.rozhlas.cz/rozhlasovypodzim>.

Severočeské divadlo Ústí nad Labem, Webová stránka, Dostupné z: <www.operabalet.cz>.

Slezské divadlo Opava. Webová stránka, Dostupné z: <www.divadlo-opava.cz>.

Struny podzimu. Webová stránka, Dostupné z: <www.strunypodzimu.cz >

Šaldovo divadlo - Ceník předplatného 2013. Webová stránka, Dostupné z: <www.saldovo-divadlo. cz/usf/file/DFXS_predplatne\%20cenik\%202013.pdf>.

Šaldovo divadlo. Webová stránka, Dostupné z: <www.saldovo-divadlo.cz> 
